Article

\title{
Leadership Style and Gender: A Study of Spanish Cooperatives
}

\author{
Inocencia María Martinez-Leon ${ }^{1, * \mathbb{C}}$, Isabel Olmedo-Cifuentes ${ }^{1}$, MCarmen Martínez-Victoria ${ }^{2}$ \\ and Narciso Arcas-Lario ${ }^{1}$ (D) \\ 1 Business Administration Department, Universidad Politécnica de Cartagena, Calle Real, 3, \\ 30201 Cartagena, Spain; isabel.olmedo@upct.es (I.O.-C.); arcas.lario@upct.es (N.A.-L.) \\ 2 Economics and Business Department, University of Almería, Ctra. Sacramento s/n, \\ La Cañada de San Urbano, 04120 Almería, Spain; mcmvic@ual.es \\ * Correspondence: ino.martinez@upct.es
}

Received: 20 May 2020; Accepted: 19 June 2020; Published: 23 June 2020

\begin{abstract}
The growing global need for social cohesion and sustainable development gives visibility to cooperatives because their principles help to achieve these objectives and the adoption of Sustainable Development Goals (SDGs). Among them, gender equality policies are in the forefront. This paper explains how cooperatives contribute to women's professional opportunities and to balancing the presence of women in management positions. It analyzes the predominant leadership styles and gender differences in cooperatives with a sample of 114 cooperative firms. The results show that: (a) Both transformational and transactional leadership styles are widely used; (b) no significant differences in leadership styles between men and women exist; and (c) the composition of management teams results in significant leadership style differences. The transformational style is less often used in mixed teams with a male majority and a woman president, and most often used in homogeneous teams (made up of only men or only women). Transactional leadership is more frequently implemented in teams made up only of women than in mixed masculine teams with a female president. These findings identify women's leadership styles in cooperatives, pointing out their difficulties and introducing innovative proposals for contributing to their success and the achievement of SDGs in cooperatives.
\end{abstract}

Keywords: cooperatives; sustainability; Sustainable Development Goals (SDGs), leadership style; transformational leadership; transactional leadership; gender differences

\section{Introduction}

The need for social development and cohesion to reduce inequality and contribute to achieving more responsible growth models calls for other ways of carrying out business and economic activities in concordance with the values of sustainability.

Sustainable development refers to the "development that meets the needs of the present without compromising the ability of future generations to meet their own needs" [1], which has an impact on the wellbeing of individuals and entire societies and reinforces social capital. This type of development consequently requires a new way of organizing economies [2], with models that are more respectful toward the environment and social justice and that promote shared, safe, and sustainable progress, as well as supporting equality. This is the challenge we are currently facing.

The road map of the United Nations (UN) is exhibited in the 2030 Agenda for sustainability, which establishes seventeen interconnected Sustainability Development Goals (SDGs). The implementation and success of this Agenda rely on member countries' own sustainable policies and programs to lay a solid economic foundation. This will only be possible if wealth is shared and 
income inequality is combated. For this reason, dynamic, sustainable, innovative, and people-centered economies must be built, promoting, in particular, social economy enterprises (SEEs).

The Social Economy (SE) involves organizations, in particular cooperatives (jointly with mutual benefit societies, associations, foundations, and social enterprises), that pursue social objectives in the core of their economic activity [3-5]. They also try to preserve income and employment during economic downturns [6], as well as developing social and environmental goals closely related to sustainable development and SDGs [7]. SE has given a spectacular response to the "crisis of the welfare state", attending to social needs that are not properly provided either by the public sector or by private capitalist agents [3]. In the European Union in general and Spain in particular, governments are moderately proactive in terms of recognizing and supporting SSEs [7-9]. In Spain, the SE is recognized as a cornerstone to economic recovery and sustainable and inclusive economic growth, especially in rural areas [10]. The Spanish government underlines the contribution of SEEs to sustainability through the Spanish Social Economy Strategy 2017-2020, a pioneering approach at the European level.

The members of the Spanish Social Economy Employers' Confederation (CEPES) consider that Spanish SEEs are committed to the 2030 Agenda. In particular, the members of CEPES assess how their entities contribute to SDGs in the areas of [9]: (a) Employment and the integration of groups excluded from the labor market (SDG 8: 13.91\%); (b) access to quality education for everyone (SDG4: $13.16 \%$ ); (c) gender equality (SDG5: 12.03\%); (d) responsible consumption and production (SDG12: $9.02 \%$ ); (e) actions to fight climate change (SDG13: 9.02\%); (f) good health and well-being (SDG3: 8.27\%); and (g) lessening social inequalities (SDG10: 1.88\%); among others.

In particular, cooperatives display a social mission where the nature of their values and principles (such as autonomy, responsibility, democracy, equality, equity, and solidarity) make them suitable to address sustainable development's triple bottom line of economic, social [11-13], and environmental objectives [14,15]. These principles give voice to their members in shaping cooperatives because they actively participate in setting their policies and making decisions [16]. This organizational system drives social wellbeing among members and strengthens the role of stakeholders. Battilana et al. [17] and Hudon and Hytbrechts [12] point out that cooperatives can more easily move toward a balanced trade-off among social, environmental, and financial performance. Therefore, cooperatives are the backbone of SEEs [18,19], promoting economic growth from a sustainable standpoint.

Cooperatives are able to accelerate SDG implementation because of their people-centered business model, which combines competitiveness, transparency, sustainability, solidarity, and social innovation [14]. Mozas and Puentes [20] indicate the key characteristics of cooperatives (democratic control, equity, equal voting rights, profit-sharing, social responsiveness, job security, and social inclusion) that make the transition toward a more responsible model easier. Cooperatives provide access to social services, give economic opportunities to their members, create employment, empower the disadvantaged to defend their interests, do not discriminate, and offer support and access to economic resources. All of the above are related to SDG 1 (reduction of poverty) and SDG 10 (reduced inequalities). These entities also promote sustainable and productive employment and decent work for all men and woman. Based on a democratic structure with smaller gender pay gaps among members in comparison with other companies, SDG 8 (decent work and economic growth) is covered. Moreover, cooperatives seek to integrate people into the organizations, achieving gender equality and the empowerment of all women (SDG 5: Gender equality) [14,21].

There is no doubt that the direction of SDGs is in line with the principles and values of the SE [12]. Therefore, the role of cooperative enterprises in the promotion and expansion of SDGs could be decisive $[8,10,15,20,22]$.

Furthermore, cooperatives have demonstrated stability and have even increased their turnover and employment rates during the prior recession [23,24]. In particular, the previous deep economic crisis caused the majority of recovering companies to become cooperatives of associated work. Cooperatives consequently facilitate the territorial development of their regions [25]. Therefore, the contribution of these companies is undisputed today, with cooperatives having an important presence in many business 
sectors. There are estimated to be 250,000 cooperatives in the European Union, which employ more than 5.4 million people [26]. In this context, the participation of SEEs in the design and implementation of SDGs is supported by European Institutions and International Organizations such as the UN.

As women still need to improve their socio-professional position [27], their incorporation into cooperatives is very attractive. As a result, new ways of managing organizations are implemented, with social, ethical, and gender implications, and with impact on the performance of the organization, since female managers may act as agents of change and innovation [28]. Consequently, it is important to discover what the real situation of Spanish women in cooperative management is, especially 10 years after the approval of the Spanish equality law, which significantly affects the presence of women in management. Leadership styles may play a key and differentiating role in cooperative management because they determine the strategy [29,30], decision-making process [31], employee behavior [32], and organizational results [33].

In light of the foregoing, this study addresses the main research gap discovering the predominant leadership styles of Spanish cooperative managers and whether there are gender differences in leadership style implementation. As cooperatives offer a non-traditional context to make business, being value-based organizations, it becomes necessary to analyze the effect of value systems on leadership styles. Few investigations have focused on leadership styles in cooperatives, which makes this study essential. In addition, previous studies have not investigated gender differences in leadership behavior in cooperatives, including the influence of management team composition on this behavior. To do this, an empirical study has been carried out with 114 cooperatives. Moreover, the following research questions have been posed: (1) Which leadership style is more often implemented by cooperative managers? (2) Are there gender differences in the predominant leadership styles of Spanish cooperative managers? and (3) Are there gender differences in the predominant leadership styles developed by cooperative managers according to the management team they lead? With these analyses, other aspects could be explored in cooperatives, such as: a) How could female managers obtain better success in their roles of leading management teams in cooperatives? (b) Which cooperative management teams are more effectively managed by female directors? (c) What organizational policies and recommendations should be implemented in cooperatives to improve the assessment/consideration of female managers? (d) Can managers identify the barriers that prevent them from implementing their leadership styles effectively in cooperatives? (e) How can the female directors of cooperatives feel more satisfied in their role? (f) How can the coexistence of different leadership styles be compatible in the same cooperative? (g) How can the most talented managers be retained in cooperatives? (h) How can cooperatives contribute to improving gender equality? (i) What is the most important contribution of cooperatives to SDGs?

This study shows similarly high levels of both transformational and transactional leadership styles among managers of cooperatives and does not reveal significant gender differences in their use in the cooperatives analyzed. If the composition of management teams is considered, some gender differences in implementation are found. Transformational leadership is more often implemented by male management teams and female management teams than by mixed male management teams with a female president. Transactional leadership is more often implemented by female teams than by mixed male management teams with a female president. These findings show important information to be analyzed and discussed, introducing some practical and social implications and recommendations.

The paper is divided into six sections. The first part introduces the concepts of cooperatives as key actors in sustainable development. In the second part, leadership styles are analyzed, considering gender differences and management team composition. In the third part, the methodology is reported as well its successful implementation. After this process, the results are presented in the fourth section, and the most important findings are shown in the discussion section. Finally, conclusions and implications are included in the last section, as well as limitations and future research lines. 


\section{Theoretical Review}

\subsection{Cooperatives and Leadership Style}

Leadership is a dynamic social process in which leaders influence followers to carry out tasks and achieve expected outcomes. In value-based organizations, leaders' behavior is particularly influenced by this context [34]. Cooperatives prioritize social objectives, where self-help, democratic self-management, solidarity, and cooperation guide their activities. Leaders should behave according to these principles, understanding members' needs and satisfying their requests. However, governance issues may arise when leaders are not adequately applying these principles. The reason is that managerial teams in cooperatives try to achieve the same goals associated with efficiency and productivity, related to competitiveness and survival, as other organizations do and are not always focused on equity and redistribution. Thus, cooperatives need to transform their patterns of management and investment to accomplish most of their specific values and principles as well as the SDGs. To accomplish this transformation, leadership plays a key role because it "inspires others to work together to achieve a common goal in an organization" [35]. In this case, leaders may implement new managerial considerations because new policies of change are necessary for new stakeholders, such as enhancing bargaining power, building coalitions, and shaping policy processes [7]. Leaders may thereby play a significant and strategic role in addressing different SDGs in their cooperatives. Hence, their leadership styles are very important for cooperatives.

Leadership style refers to the relatively stable patterns of behavior used by leaders [36,37]. The importance of leaders lies in their primary role of designing and implementing strategy [29,30], as well as in the way in which they face organizational problems and develop and evaluate potential decisions [31]. Likewise, leadership style determines the behavior of the company's employees [32], affecting teamwork, the organizational environment, and outcomes [38]. Thus, it has a direct effect on decision-making and organizational results.

The most prevalent classification of leadership style distinguishes three types: Transformational, transactional, and "laissez faire" [36], although the latter is less often considered because it is characterized by a lack of leadership, which is quite difficult to find in cooperatives of associated work due to the presence of working partners.

Transformational leadership is characterized by leaders who incite their followers to act beyond their personal interests and to focus on organizational objectives, motivating them to achieve more than initially expected. Hence, a transformational leader drives the achievement of individual and collective standards of excellence through the establishment of a common vision and mission. The five components of transformational leadership differentiated by Bass [39] and Bass, and Avolio [40] are: Idealized attributed influence (leaders' charisma), idealized behavior influence (admiration), inspirational motivation, intellectual stimulation (creativity and innovation), and individualized consideration.

As SEEs develop a transformative change based on their principles and practices founded on the five dimensions of sustainable development (a) economic: employment creation, local economic development, and women's economic empowerment, (b) social: decent work, work integration, basic needs of provisioning, (c) environmental: protection, community-based natural resource management, and stewardship, among others, (d) cultural: increasing solidarity values, ethics, social justice, and community, and (e) political/governance: collective action, empowerment, democratic governance, and active citizenship) [7], their potential transformative nature requires transformational leaders. In cooperatives, leaders' values and principles should be based on cooperative principles (voluntary and open membership, democracy, economic participation, autonomy and independence, education and information, cooperation among cooperatives, and concern for the community). In this context, leaders are expected to operate according to these internal values to achieve organizational goals and sustainable objectives. In particular, they should work together to meet community members' needs and achieve their sustainable development thorough policies accepted by cooperative members (concern for the community) as well as strengthening the cooperative movement by working with other 
cooperatives (cooperation among cooperatives) and facilitating the integration of SDGs in cooperative work practices. Democratic member control, economic participation, and autonomy facilitate other SDGs: Gender equality (SDG 5), decent work and economic growth (SDG 8), and the reduction of inequalities (SDG 10). These activities require leaders to play a clear transformational role. Moreover, transformative change "emphasizes the key role that collective action and associative practices can play in development and change, as well as the political empowerment of disadvantaged or subaltern groups" [7], which can be established through transformational leaders. Therefore, transformational leaders are fundamental in cooperatives.

Transactional leadership refers to a transaction or contract with the followers, where employees perform their tasks, reaching objectives and organizational goals, and in exchange, the leader provides them with economic compensation and other types of reinforcement [41]. Thus, this leadership style is focused on a relationship of exchange between the leaders and their followers in a way that the interests of both are met [42]. When it is well applied, it achieves positive results in the satisfaction and performance of the workforce. Transactional leaders exhaustively monitor the activity of their subordinates (management by exception) with the purpose of avoiding possible errors or deviations from established procedures or norms [41]. Therefore, they only know how to influence their followers by using rewards or punishments [43], depending on the quality of the work performed (contingent reward) [44].

Bass and Avolio [40] differentiate two factors of transactional leadership: Contingent reward and management by exception (corrective actions taken by leaders only when the results are not up to expectations). Cooperative values also influence the implementation of transactional leadership in cooperatives. Members' economic participation is one of the most important cooperative values, mainly among women [45]. This aspect is key for working partners and may be an indicator of the importance that a fair and equal remuneration system for employees and working partners has on leaders (contingent reward), guaranteeing gender equality, responsibility, solidarity, and even autonomy. In fact, as cooperatives are user-owned (financing), user-controlled (steering and leading the business), and user-benefit (receiving the surplus according to their use) firms in which their members adopt different roles, such as owners, users, managers, and/or beneficiaries [46-48]; some cooperative's members are working partners of the cooperative and have made important investments in them, paying special attention to their returns and the reward system.

On the other hand, cooperative leaders need to keep the organization running smoothly, avoiding problems and mistakes among their members arising from different levels of performance and productivity, developing management by exception; which favors equality, equity, responsibility, solidarity, and autonomy among cooperative members. Working partners demand strict control over improper behaviors and poor results in the cooperative. Therefore, cooperative leaders may develop a high level of transactional leadership that ensures good performance and business results.

Cooperative values and their orientation toward sustainability and SDGs play a significant role in the way transformational and transactional leaderships are implemented. Transformational leadership may be key for cooperative leaders due to the transformative change of cooperatives in society, which demand transformational leaders who inspire their followers to accomplish more than what is expected of them [49].

Likewise, constant change in the business world brought about by knowledge, innovation, cultural diversity, sustainability, and the greater complexity of organizations is not outside the scope of cooperatives, which should adapt their leadership styles to emerging necessities. The growing presence of women in cooperatives implies an influential transformative change and greater transformational leadership. Therefore, transformational leadership seems to have a more important role than transactional leadership in cooperatives. Thus, the following hypothesis is proposed:

Hypothesis 1 (H1). The transformational leadership style is more often implemented in cooperatives than transactional leadership. 


\subsection{Leadership Styles According to Gender}

Specific characteristics in the leadership styles of men and women have been widely analyzed.

While there is not a clear indication that women leaders employ different leadership styles than men [50-53], some articles have found differences in their behaviors (women vs. men) based on different expectations, stereotypes, and the work context.

Rosener [54] carried out the first study in which the leadership style of male and female managers was evaluated. She concluded that women leaders demonstrated transformational leadership mainly in organizations, which had a culture created by the women themselves and which was more in tune with their abilities. In contrast, men described their leadership style in terms of exchanges with their subordinates (transactional leadership).

Eagly and Johnson [55] carried out a meta-analysis based on personality traits and behavior where they found gender differences in leadership styles, describing women as more democratic and men as more autocratic.

However, these results are contrary to those obtained by Komives [50] in a non-traditional context (university residence halls), where, in general, male and female directors evaluated their leadership styles in a similar way. Nevertheless, their perceptions toward how they viewed transformational leadership varied substantially. While women considered that styles based on relational accomplishment contributed to their transformational leadership, men perceived that their styles of direct power (control and direction) were what contributed to their transformational leadership. Therefore, gender stereotypes affect the kind of leadership developed.

Druskat [56], in a study carried out on 6,359 men and women about their immediate superiors in Catholic religious orders, obtained identical results to those obtained by Rosener [54]. She concluded that "women as a group possess a different set of values (they value relationships, collaboration and discussion), and this leads them to implement a different leadership style than that of men" (p. 103). Consequently, she attributes behavior more oriented toward transformational leadership to women and transactional leadership to men. This study also highlights the importance of context in the adoption of transformational leadership by women, pointing out that if the organization is "traditional" (bureaucratic, rigid, and markedly masculine), gender differences are masked since women adapt to the masculine norms and expectations in these types of organizations. In contrast, in "non-traditional" organizations, women are free to exhibit their "true leadership style".

For Bass, and Avolio [44], men and women adopt different leadership styles due to: (a) The stereotypes that subordinates have toward women in leadership positions since they expect worse performance from them; (b) the fact that male leaders are evaluated more strictly when they do not fulfill subordinates' expectations; (c) women's greater interest in others and their social sensitivity as well as their experience in child-rearing and education, which involve qualities corresponding to transformational leadership; and (d) the different values that men and women have as men place more importance on hierarchical relationships with values based on rights and justice, while women's values are more oriented toward social relations, with values focused on care and responsibility $[36,44]$.

Bass et al. [57] confirmed the results obtained by Bass and Avolio [44], concluding that female leaders demonstrated a more transformational leadership style, with behavior more oriented toward "contingent reward" than men, who demonstrated a more passive leadership style.

Along the same lines, Eagly and Johannesen-Schmidt [37] confirmed that women's leadership styles were more oriented toward "individualized consideration" and "contingent reward", which implies that they are more considerate and attentive to their subordinates, fostering enthusiasm and optimism.

In contrast, Van Engen et al. [51] corroborated the absence of differences in the leadership styles of male and female leaders. However, they detected that the differences between "transformational" and "people oriented" is exclusively and surprisingly due to the city in which the departments are located. Context, therefore, affects the leadership developed by genders. 
In this same vein, Vecchio [52] did not find any evidence of significant differences between the leadership styles employed by men and women, nor that any clear superiority of one over the other existed.

In contrast, the study carried out by Eagly and Carli [58] shows that there are certain qualities that women have and men do not, which correspond to the stereotypically feminine. These "feminine" qualities promote a leadership style that is effective when facing situations of constant change and intense competition. Therefore, as Rosen and Jerdee [59] proposed, women managers provide certain advantages in leadership due to their qualities but suffer the disadvantage of prejudice when their competence as managers is evaluated, especially in masculine business environments.

Van Engen and Willemsen [60] demonstrated that women tend to be more democratic and have a more transformational leadership style, while they did not find gender differences in other styles of leadership. For these authors, the gender differences in leadership styles are contingent on the context in which the men and women work. The type of organization in which the leader works and the setting of the study proved to be moderators of gender differences in leadership styles.

From the previously mentioned results, some researchers justify certain differences in the way men and women lead based on different expectations and stereotypes. The characteristics of a female leadership style are interpersonal orientation, consideration, and democratic relations; while a male leadership style is characterized by task-related orientation, instrumentality, and autocratic relations $[37,55,61]$.

Nevertheless, if we focus on those studies that examine gender differences in transformational leadership behavior, we do see discrepancies. Various studies reveal that women show more transformational leadership behavior in the workplace than men [37,44,54,56,57,60,62-65]. However, there have been studies that have not detected gender differences in transformational leadership behavior [66-69]. On the other hand, authors such as Komives [50], Van Engen et al. [51], Vecchio [52], or Stewart and McDermott [53] conclude that the leadership styles of men and women appear to be the same. It is important to take into account that the context and the type of organizations analyzed may be a factor that influence the presence of gender differences in leadership styles $[50,51,56]$.

In the cooperative context considered in this study, Fregidou [70] states that women have a different scale of values since they prioritize social issues and aspire to power, not with the intention of controlling others but of achieving sustainable development, and they also analyze the consequences of their decisions on others. All of this is reflected in their leadership style; presumably more transformational. Other research in the cooperative context is that developed by Berenguer et al. [71], who concluded that gender stereotypes can induce different values and behaviors in both genders, which are transferred to leadership style. However, Berenguer et al. [71] do not consider the specific characteristics of transformational and transactional leadership styles. Finally, Eti-Tofinga et al. [34] established that Fijian cooperatives have hybrid leadership where several styles (not only transformational and transactional but also democratic, authoritative, and visionary, among others) are combined, based on the results of their qualitative interviews. Nevertheless, they considered that transformational leadership is dominant because it helps to fix rules, values, cultural roles, standards, and processes [34].

Despite the previous research, the absence of empirical studies that analyze gender differences in transformational and transactional leadership styles in the cooperative context does not aid in identifying their existence and importance. In any case, an extensive review of the literature, which presents unequal results about gender differences in leadership styles and the minimal number of studies that focus on SEEs and cooperatives in particular, motivate the following hypothesis:

Hypothesis 2 (H2). There are no gender differences in the leadership styles of male and female managers in cooperatives. 


\subsection{Perception of Leadership Styles According to Management Team Composition}

In recent years, gender diversity in management teams and boards of directors has become an important issue that has attracted the attention of politicians, shareholders, and academics [28,72,73]. Consequently, a large number of studies have analyzed the impact of female presence on boards of directors in different aspects of management [74], decision-making [75], risk-taking [76], general performance of the company [77], and company value [78]. However, there is little direct evidence about the composition of management teams and leadership implemented in SEEs, despite the fact that Spain is one of the pioneers in developing laws that favor the presence of women on boards of directors (Organic Law 3/2007 for Effective Equality between Women and Men). Furthermore, in Spain in general, and in SEEs in particular, the separation between managers and working partners is slight, decisively affecting methods of management. For these reasons, this study is justified.

However, the composition of the management team might or might not influence the leadership style developed. The previous studies carried out on gender differences in leadership reflect that, traditionally, female authority is less well accepted than male authority [79-81]. Subsequently, women who have assumed positions as leaders are not as highly considered as their male peers [80] and they encounter economic and social reticence [82] when exercising their authority [81,83]. In addition, employees lean toward male supervision [84] observing that $51 \%$ of the participants have no preference, with $66 \%$ of the remaining $49 \%$ prefer having a man as their superior rather than a woman [85].

Among the reasons explaining why subordinates resist having female managers/leaders, we can highlight two. First, there is an imbalance [86,87] or incongruence [88] between the behaviors and traits linked to effective leaders (for example, assertiveness, agency, confidence, and decisiveness) and the typical traits used to describe women (warmth, politeness, and flexibility) $[89,90]$. Thus, masculine stereotypes are more closely related to successful managers [91,92] and with influential people in general [93]. Therefore, the role of leader is more frequently associated with a man than with a woman $[86,88,94]$.

This situation explains why women with identical credentials to men are perceived to be less competent. In fact, women must work harder and demonstrate greater performance than men in order to be considered equally capable [95]. At the same time, women find themselves in a contradictory situation [96], since male managers are considered to be more competent than female managers, and consequently, more worthy of admiration and respect; women are thus less well accepted, respected, and valued than their male counterparts when they are leaders.

The explanation for this reality can be found in the Theory of Social Roles, since people's behavior conforms to social expectations of gender roles [88]. In function of such roles, women are expected to have a different character than men $[80,88,92]$.

The second reason that accounts for why subordinates resist having female managers/leaders is that society tends to penalize gender variations; that is, females and males who act in discrepancy with traditional gender stereotypes $[82,97,98]$. For example, researchers have found that women leaders are subject to disadvantages for not fulfilling the prescribed belief that they are communal (this is to say, they display a "lack of communality") [80] and for transgressing gender restrictions about women not being dominant ("penalization for domination") [99]. Williams and Tiedens [100] demonstrated that men are less harshly punished than women for explicit expressions of dominance, after carrying out a meta-analysis of 63 studies, which encompass 39 years of research. Likewise, it appeared that the same amount of formal power can be perceived as "too much" in the hands of a woman, but not enough for a man, and that powerful women are threatening [99] and not trustworthy [101]. Since women are not usually associated with power and supremacy [91,92], when a female (instead of a male) takes a powerful position, power differentials could appear among her subordinates. This means that the same amount of respect and admiration, which could legitimize a man's power, might be detrimental to a woman leader carrying out her role.

All the above explains why women continue to be underrepresented in decision-making and in powerful positions [102] and why they experience a "glass ceiling" [27]; that is, a "barrier so subtle 
that it is transparent, yet so strong that it prevents women and minorities from moving up in the management hierarchy" [103].

However, the makeup of the management team and the type of organization in which the male or female manager works has a clear influence on the perception of leadership styles implemented by men and women. Eagly and Karau [88] analyzed the emergence of leaders in small groups such as management teams. After a meta-analysis, they concluded that when a group is created without leaders, men seemed to rise as leaders more frequently than women. Nevertheless, the women who emerged as leaders did so largely as "social leaders" who contributed to social relations. In the same vein, Heilman and Haynes [104] discovered the tendency to assume that in successful teams made up of a man and a woman, the man was in large part responsible for the success of the team unless the contribution of the woman to the final product was unequivocally established.

In accordance with the theoretical review carried out and considering the characteristics of cooperatives, we pose the following hypotheses:

Hypothesis 3 (H3). There are no differences in the leadership styles implemented by management teams led by men and women in cooperatives.

Hypothesis 4 (H4). There are no differences in the leadership style implemented by management teams made up entirely of men and those made up entirely of women in cooperatives.

\section{Methodology}

\subsection{Sample}

To carry out this study, Spanish cooperatives of associated work received email messages inviting them to take part in a study on leadership styles. To do so, they had to anonymously fill out a questionnaire with 27 questions, each one with a variable number of items.

Following this process and after the elimination of those questionnaires that had not been completely filled out, we obtained information from 114 cooperatives of associated work, with a predominance of those involved in education (91), which represented $79.8 \%$ of the total sample. The rest of the cooperatives were distributed among diverse areas (construction, professional activities, or agriculture). The choice of associated work cooperatives is justified because they represent $55.5 \%$ of the total number of cooperatives in Spain, and their shareholders are workers of the cooperative at the same time. In terms of size, $49.5 \%$ of the cooperatives reported revenue of less than or equal to 1 million euros, $20 \%$ greater than 1 million euros and less than or equal to 2 million euros, and $30.5 \%$, greater than 2 million euros and less than or equal to 10 million euros. They had an average of 25.5 members, of which 9 were men and 16.5 were women. The entities that participated had an average of 39.6 workers; 14.6 men and 25 women.

\subsection{Variables and Data Analysis}

To measure the variables related to leadership styles, the "Multifactor Leadership Questionnaire" (MLQ) was used [105-107], which has been validated in previous studies [108-110]. The MLQ is one of the most frequently used instruments to measure leadership in the field of organizational psychology [111]. Each one of the items of the variables (Table 1) was evaluated on a 5-point Likert scale ( 1 equals total disagreement and 5 , total agreement). We focused on the two main leadership styles analyzed: Transformational and transactional. 
Table 1. Mean values of transformational and transactional leadership scales.

\begin{tabular}{|c|c|c|c|c|}
\hline \multirow{2}{*}{ Leadership } & \multirow{2}{*}{ Component } & \multirow{2}{*}{ Items } & \multicolumn{2}{|c|}{ Mean } \\
\hline & & & Men & Women \\
\hline \multirow{25}{*}{ 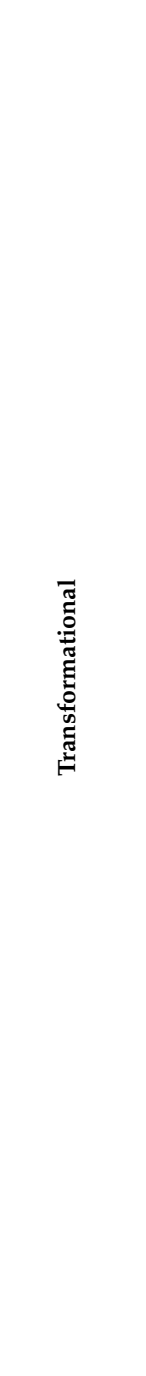 } & \multirow{5}{*}{$\begin{array}{l}\text { Idealized influence attributed } \\
\quad(\text { Cronbach's } \alpha=0.857)\end{array}$} & 1. I make the others feel proud of working with me & 4.46 & 4.34 \\
\hline & & $\begin{array}{l}\text { 2. For the good of the group, I am willing to look beyond } \\
\text { my own interest }\end{array}$ & 4.24 & 4.22 \\
\hline & & 3. I act in a way that gains the respect of the others & 4.46 & 4.37 \\
\hline & & 4. I appear confident and sure of myself & 4.38 & 4.50 \\
\hline & & AVERAGE & 4.35 & 4.29 \\
\hline & \multirow{5}{*}{$\begin{array}{l}\text { Idealized influence behavior } \\
\quad \text { (Cronbach's } \alpha=0.802)\end{array}$} & 5. I express my most important values and beliefs & 4.38 & 4.38 \\
\hline & & $\begin{array}{l}\text { 6. I believe it is important to have a clear objective in } \\
\text { actions taken }\end{array}$ & 4.67 & 4.58 \\
\hline & & $\begin{array}{l}\text { 7. I keep the moral and ethical consequences of the } \\
\text { decisions I make in mind }\end{array}$ & 4.56 & 4.43 \\
\hline & & $\begin{array}{l}\text { 8. I emphasize the importance of having a shared } \\
\text { mission }\end{array}$ & 4.42 & 4.33 \\
\hline & & AVERAGE & 4.48 & 4.41 \\
\hline & \multirow{5}{*}{$\begin{array}{l}\text { Inspirational motivation } \\
\text { (Cronbach's } \alpha=0.915 \text { ) }\end{array}$} & 9. I try to envision the future in an optimistic way & 4.25 & 4.30 \\
\hline & & 10. I speak enthusiastically about goals to reach & 4.30 & 4.20 \\
\hline & & 11. I create a motivating vision of the future & 4.24 & 4.35 \\
\hline & & 12. I express confidence that goals will be reached & 4.27 & 4.33 \\
\hline & & AVERAGE & 4.23 & 4.26 \\
\hline & \multirow{5}{*}{$\begin{array}{l}\text { Intellectual stimulation } \\
\text { (Cronbach's } \alpha=0.853)\end{array}$} & $\begin{array}{l}\text { 13. I usually evaluate beliefs and assumptions critically } \\
\text { to see if they are appropriate }\end{array}$ & 4.15 & 4.15 \\
\hline & & $\begin{array}{l}\text { 14. When solving problems, I try to consider them in } \\
\text { different ways }\end{array}$ & 4.13 & 4.18 \\
\hline & & $\begin{array}{l}\text { 15. I help others to look at problems from different } \\
\text { points of view }\end{array}$ & 4.31 & 4.17 \\
\hline & & 16. I suggest new ways of working to others & 4.19 & 4.27 \\
\hline & & AVERAGE & 4.15 & 4.21 \\
\hline & \multirow{5}{*}{$\begin{array}{l}\text { Individualized consideration } \\
\quad(\text { Cronbach's } \alpha=0.811)\end{array}$} & 17. I spend time teaching and guiding & 4.19 & 4.00 \\
\hline & & $\begin{array}{l}\text { 18. I treat the others as individuals, not only as members } \\
\text { of a group }\end{array}$ & 4.57 & 4.63 \\
\hline & & $\begin{array}{l}\text { 19. I believe each person has unique needs, abilities, } \\
\text { and aspirations }\end{array}$ & 4.24 & 4.32 \\
\hline & & 20. I help the others develop their strengths & 4.28 & 4.22 \\
\hline & & AVERAGE & 4.33 & 4.40 \\
\hline \multirow{10}{*}{ 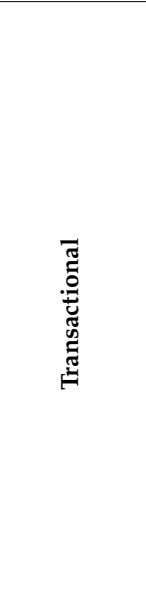 } & \multirow{5}{*}{$\begin{array}{l}\text { Contingent reward } \\
\text { (Cronbach's } \alpha=0.876)\end{array}$} & 1. I help the others as long as they make an effort & 4.24 & 4.41 \\
\hline & & $\begin{array}{l}\text { 2. I clarify and specify the responsibility of each one to } \\
\text { achieve their objectives }\end{array}$ & 4.37 & 4.32 \\
\hline & & $\begin{array}{l}\text { 3. I make it clear what each one will receive if they reach } \\
\text { their goals }\end{array}$ & 3.98 & 3.95 \\
\hline & & $\begin{array}{l}\text { 4. I express my satisfaction when others achieve what is } \\
\text { expected of them }\end{array}$ & 4.37 & 4.32 \\
\hline & & AVERAGE & 4.24 & 4.25 \\
\hline & \multirow{5}{*}{$\begin{array}{l}\text { Management by exception } \\
\text { (Cronbach's } \alpha=0.869)\end{array}$} & $\begin{array}{l}\text { 5. I try to pay attention to the errors and departures from } \\
\text { required standards }\end{array}$ & 4.13 & 4.33 \\
\hline & & $\begin{array}{l}\text { 6. I pay all my attention to errors, complaints, } \\
\text { and mistakes, and their handling }\end{array}$ & 4.27 & 4.13 \\
\hline & & 7. I monitor all the errors that have occurred & 4.15 & 4.23 \\
\hline & & $\begin{array}{l}\text { 8. I direct my attention to failures or errors in order to } \\
\text { achieve standards }\end{array}$ & 4.00 & 4.18 \\
\hline & & AVERAGE & 4.24 & 4.21 \\
\hline
\end{tabular}

The reliability and internal consistency of the two types of leadership analyzed and their components were measured using Cronbach's alpha coefficients, whose values are given in Table 1. 
Regarding the study of the data, a mean analysis, mean differences test, and a one-factor ANOVA test have been carried out.

\section{Results}

Table 1 shows the mean values for men and women in each of the items, which make up transformational and transactional leadership styles. Cronbach's alpha is a method of internal consistency based on the average of the correlations of the items, which allow for the quantification of the level of reliability on a measurable scale [112]. Cronbach $\alpha$ for each of the components of both leadership styles has also been included. They obtained values between 0.802 and 0.915 , which demonstrates the high reliability of the items.

Table 2 shows the mean values for men and women in each of the components of the leadership styles studied after performing the arithmetic mean of each of the items, which comprised every one of them. Likewise, the mean values of each component were averaged to obtain mean values for each leadership style (Table 2).

Table 2. Comparison of averages of leadership styles in cooperatives of associated work in the region of Murcia.

\begin{tabular}{cccc}
\hline Variable & Total & Men & Women \\
\hline Transformational Leadership & $\mathbf{4 . 3 0}$ & $\mathbf{4 . 3 0}$ & $\mathbf{4 . 3 1}$ \\
\hline Idealized influence attributed & 4.33 & 4.35 & 4.29 \\
\hline Idealized influence behavior & 4.45 & 4.48 & 4.41 \\
\hline Inspirational motivation & 4.24 & 4.23 & 4.26 \\
\hline Intellectual stimulation & 4.17 & 4.15 & 4.21 \\
\hline Individualized consideration & 4.36 & 4.33 & 4.40 \\
\hline Transactional leadership & $\mathbf{4 . 2 4}$ & $\mathbf{4 . 2 4}$ & $\mathbf{4 . 2 3}$ \\
\hline Contingent reward & 4.24 & 4.24 & 4.25 \\
\hline Management by exception & 4.23 & 4.24 & 4.21 \\
\hline
\end{tabular}

* Transformational and Transactional leaderships include their respective dimensions above.

The results reveal that the transformational leadership style predominates (4.30 over 5), especially in idealized influence behavior and individualized consideration, since cooperatives of associated work favor them due to their values and democratic relations, interpersonal orientation, and individualized consideration. This is because of the high percentage of staff members who are also working partners, which makes those characteristics that before only belonged to women now widely shared by male leaders as well. In addition, male leaders are increasingly reluctant to impose a leadership style oriented toward tasks and autocratic relations (masculine), because this style is completely at odds with the cooperative values and culture, which govern cooperatives of associated work (mutual assistance, responsibility, democracy, equality, equity, and solidarity). This is reflected in their leadership styles. However, transactional leadership also receives a high score (4.24 over 5), with both components displaying similar importance. The high scores given to the components of transactional leadership could be a consequence of the characteristics of cooperatives (SEEs), where the majority of the workforce are also members of the organization, implicated in the achievement of goals and with management by exception being fundamental. Therefore, hypothesis 1 is not supported because cooperatives seems to combine transformational and transactional leadership styles as established by Bass and Avolio [44] or Eti-Tofinga et al. [34].

The results do not show gender differences in the leadership styles implemented in Spanish cooperatives of associated work (Table 2). Nevertheless, a mean differences test was performed, which confirms that no significant differences existed, confirming hypothesis 2 of this study and the contributions made by Maher [66], Manning [67], Mandell and Pherwani [68], and Brown and Reilly [69]. 


\subsection{Influence of the Composition of the Management Team on Leadership Style}

With the objective of examining the results obtained and contrasting hypotheses 3 and 4, the composition of the management teams of cooperatives of associated work were considered to see whether this has an influence on the leadership styles developed. To do this, a variable that characterized seven types of management teams was created: (a) Female team: only women, (b) Mixed female team: majority of women + female president, (c) Mixed female team with male president: majority of women + male president; (d) Mixed team: equal number of men and women with a male or female president; (e) Mixed male team with female president: majority of men + female president; (f) Mixed male team: majority of men + male president; and (g) Male team: only men.

Regarding transformational leadership, Table 3 shows significant differences after carrying out the ANOVA test. We can observe significant differences between mixed male teams with a female president (with a lower score, 3.74) and the other three types of teams: Female teams (4.61), mixed female teams with a male president (4.48), and male teams (4.54). Regarding transactional leadership, female teams have significant differences compared to mixed male teams with a female president (4.36 and 3.56, respectively). Therefore, hypothesis 3 is rejected since the mixed male team with a female president develops less transformational leadership than the other categories of management teams. The score of this type of team is significantly lower than the three types of teams previously mentioned (Table 3). From this, we can conclude that a greater perception in the leadership style developed is associated with men, in comparison to women $[86,88,94]$, and female leaders' performance is perceived as worse by their male colleagues [44]. In addition, the social penalty that women receive from their male colleagues can be observed [82], as well as the lower level of appreciation they provoke [80]. Moreover, we can observe that male workers tend to prefer masculine supervision over supervision by women [84] since the scores of mixed female teams with a male president are quite a lot higher than those of mixed masculine teams with a female president.

Table 3. Significant differences in the influence of management team composition on transformational and transactional leadership (ANOVA test).

\begin{tabular}{ccccc}
\hline \multicolumn{3}{c}{ Transformational Leadership } \\
\hline Management Team & Average & Management Team & Average & ANOVA Test \\
\hline Female Team & 4.61 & $\begin{array}{c}\text { Mixed Male Team with } \\
\text { Female President }\end{array}$ & 3.74 & $\begin{array}{c}0.871^{* *} \\
(0.023)\end{array}$ \\
\hline $\begin{array}{c}\text { Mixed Female Team with } \\
\text { Male President }\end{array}$ & 4.48 & $\begin{array}{c}\text { Mixed Male Team with } \\
\text { Female President }\end{array}$ & 3.74 & $\begin{array}{c}0.742^{*} \\
(0.082)\end{array}$ \\
\hline Male Team & 4.54 & $\begin{array}{c}\text { Mixed Male Team with } \\
\text { Female President }\end{array}$ & 3.74 & $\begin{array}{c}0.800^{* *} \\
(0.047)\end{array}$ \\
\hline Management team & Average & Transactional Leadership & ANOVA test \\
\hline Female Team & 4.36 & $\begin{array}{c}\text { Mixed Masculine Team } \\
\text { with Female President }\end{array}$ & 3.56 & $0.802 * *$ \\
$(0.044)$
\end{tabular}

$p<0.1^{*} ; p<0.05^{* *}, p<0.01^{* * *} ;$ a test of the variance using Bonferroni's statistical test. The numbers in parenthesis indicate the differences between each category or subgroup and the others.

Therefore, in spite of the fact that these female managers work in cooperatives of associated work and, to a large extent, implement transformational and transactional leadership, when they direct teams made up of men, the indicators related to their leadership style lower significantly. This incongruence reveals that there is a prototype of a successful leader, which is not associated with women [88] since female leaders are considered to develop lower levels of leadership than men, perhaps due to cultural reasons and gender stereotypes. From this we can deduce that female leaders are more poorly evaluated and accepted by their colleagues due to resistance against them deriving from gender stereotypes and traditional norms $[82,97,98]$ and the principles and values they develop in the implementation of their leadership. 
We can also observe that management teams formed exclusively of men or women are those that receive the highest scores in relation to transformational leadership, with no significant differences between one and the other. Thus, hypothesis 4 of this study is confirmed. The fact that gender stereotypes are fully accepted and shared among the rest of the management team facilitates an adequate assessment of the leaders and their leadership style, no matter whether the leader is a man or a woman. In the case of a female leader, the fact that her team is made up of women avoids the penalization derived from possible gender deviance and the resistance against valuing her work adequately. At the same time, this situation could facilitate respect and admiration among her colleagues, resulting in her being better accepted and more highly valued than in the rest of the management teams where women do not make up the majority.

Furthermore, Table 3 shows that female teams have a type of behavior more oriented toward transactional leadership than mixed male teams led by a woman. Different to previous studies $[54,56]$, these results indicate that teams led by women are also based on the exchange of rewards to influence their collaborators' performance.

\subsection{The Influence of Management Team Composition in the Development of Leadership Style Components}

Tables 4 and 5 show the levels of development of the components of transformational and transactional leadership styles according to the management team variable with a differentiation of seven groups. In both tables, only the significant results of the ANOVA test are shown in the comparison of the seven types of management teams.

Regarding the transformational leadership style, a leader's charisma (idealized influence attributed) is a highly implemented component in male and female teams (4.76 and 4.66, respectively), which show significant differences compared to mixed male teams with a female president (3.66). These results indicate that in homogenous groups, both male and female leaders have a great capacity to generate trust, admiration, and respect among their employees, with this capacity being superior in male management teams. The idealized influence behavior component has a higher value in female teams (4.76), and there are significant differences with mixed teams (4.26) and mixed male teams with a female president (4.00). Therefore, female directors foment charismatic behavior to a greater extent than in mixed teams, or mixed teams with greater male presence. The third factor, inspirational motivation, shows that female teams (4.61) (even with a male president: 4.55 ) have an increased capacity to motivate and transmit an attractive vision of the future, given their high average score. In addition, there are significant differences between these teams and the mixed teams (3.86) and mixed male teams with a female president (3.70). The fourth factor is intellectual stimulation and it indicates that homogeneous management teams (female and male) promote creative and innovative capacity among their employees with greater intensity ( 4.56 and 4.39 , respectively) than mixed male teams with a female president (3.41). Finally, the results do not show significant differences among management teams in the component individualized consideration, contradicting contributions made by Eagly and Johannesen-Schmidt [37].

Consequently, given that there are significant differences in behavior that management teams display globally for different components of transformational leadership, hypothesis 3 can be rejected. However, it is important to note that significant differences in the components of the transformational leadership style implemented only by male and only by female teams do not appear. 
Table 4. Significant differences in the influence of management teams on the development of the components of the transformational leadership style.

\begin{tabular}{|c|c|c|c|c|c|c|}
\hline Leadership & Component & Management Team & Average & Management Team & Average & ANOVA Test \\
\hline \multirow{9}{*}{ 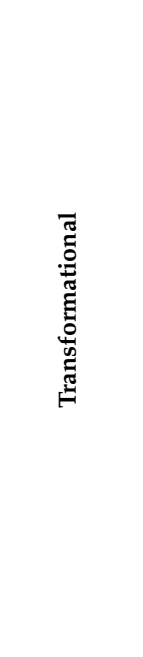 } & \multirow{2}{*}{$\begin{array}{l}\text { Idealized } \\
\text { Influence } \\
\text { attributed }\end{array}$} & $\begin{array}{l}\text { Female } \\
\text { Team }\end{array}$ & 4.66 & $\begin{array}{c}\text { Mixed Male Team } \\
\text { with Female President }\end{array}$ & 3.66 & $\begin{array}{l}1.000^{* *} \\
(0.024)\end{array}$ \\
\hline & & $\begin{array}{l}\text { Male } \\
\text { Team }\end{array}$ & 4.72 & $\begin{array}{c}\text { Mixed Male Team } \\
\text { with Female President }\end{array}$ & 3.66 & $\begin{array}{l}1.062 * * \\
(0.012)\end{array}$ \\
\hline & \multirow{2}{*}{$\begin{array}{l}\text { Idealized } \\
\text { influence } \\
\text { behavior }\end{array}$} & $\begin{array}{l}\text { Female } \\
\text { Team }\end{array}$ & 4.76 & $\begin{array}{c}\text { Mixed Male Team } \\
\text { with Female President }\end{array}$ & 4.00 & $\begin{array}{l}0.769 * * \\
(0.045)\end{array}$ \\
\hline & & $\begin{array}{l}\text { Female } \\
\text { Team }\end{array}$ & 4.76 & Mixed Team & 4.26 & $\begin{array}{l}0.507^{*} \\
(0.094)\end{array}$ \\
\hline & \multirow{3}{*}{$\begin{array}{l}\text { Inspirational } \\
\text { motivation }\end{array}$} & $\begin{array}{l}\text { Female } \\
\text { Team }\end{array}$ & 4.61 & $\begin{array}{c}\text { Mixed Male Team } \\
\text { with Female President }\end{array}$ & 3.70 & $\begin{array}{l}0.907^{*} \\
(0.073)\end{array}$ \\
\hline & & $\begin{array}{l}\text { Female } \\
\text { Team }\end{array}$ & 4.61 & Mixed Team & 3.862 & $\begin{array}{l}0.752 * * \\
(0.018)\end{array}$ \\
\hline & & $\begin{array}{l}\text { Female Mixed Team } \\
\text { with Male President }\end{array}$ & 4.55 & Mixed Team & 3.862 & $\begin{array}{l}0.695 * * \\
(0.042)\end{array}$ \\
\hline & \multirow{2}{*}{$\begin{array}{l}\text { Intellectual } \\
\text { stimulation }\end{array}$} & $\begin{array}{l}\text { Female } \\
\text { Team }\end{array}$ & 4.56 & $\begin{array}{c}\text { Mixed Male Team } \\
\text { with Female President }\end{array}$ & 3.41 & $\begin{array}{l}1.151^{* * *} \\
(0.008)\end{array}$ \\
\hline & & $\begin{array}{l}\text { Male } \\
\text { Team }\end{array}$ & 4.39 & $\begin{array}{c}\text { Mixed Male Team } \\
\text { with Female President }\end{array}$ & 3.41 & $\begin{array}{l}0.979 * * \\
(0.043)\end{array}$ \\
\hline
\end{tabular}

In the case of transactional leadership (Table 5), the evaluation of the components that comprise it varied according to the different categories of the management teams considered. So, the rewards obtained for work well done (contingent reward) has a higher value in female teams (4.12), with significant differences appearing between these and mixed male teams (3.86) and mixed male teams with a female president (3.37). Therefore, hypothesis 3 is rejected and the results obtained by Bass and Avolio [44] and Bass et al. [57] are confirmed. They concluded that female leaders displayed behavior more oriented toward "contingent reward" compared to men, who have a more passive leadership style.

Table 5. Significant differences in the influence of the composition of management teams on the development of the components of the transactional leadership style.

\begin{tabular}{|c|c|c|c|c|c|c|}
\hline Leadership & Component & Management Team & Average & Management Team & Average & ANOVA Test \\
\hline \multirow{5}{*}{ 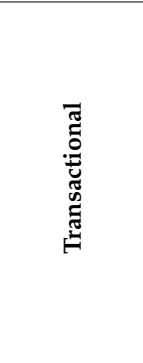 } & \multirow{2}{*}{$\begin{array}{l}\text { Contingent } \\
\text { reward }\end{array}$} & $\begin{array}{l}\text { Female } \\
\text { Team }\end{array}$ & 4.12 & $\begin{array}{c}\text { Mixed Male Team } \\
\text { with Female President }\end{array}$ & 3.37 & $\begin{array}{l}0.854^{*} \\
(0.083)\end{array}$ \\
\hline & & $\begin{array}{l}\text { Female } \\
\text { Team }\end{array}$ & 4.12 & Mixed Team & 3.86 & $\begin{array}{l}0.663^{* *} \\
(0.043)\end{array}$ \\
\hline & \multirow{3}{*}{$\begin{array}{l}\text { Management } \\
\text { by exception }\end{array}$} & $\begin{array}{l}\text { Female } \\
\text { Team }\end{array}$ & 4.61 & $\begin{array}{c}\text { Mixed Male Team } \\
\text { with Female President }\end{array}$ & 3.74 & $\begin{array}{l}0.819^{* *} \\
(0.023)\end{array}$ \\
\hline & & $\begin{array}{l}\text { Mixed Female Team } \\
\text { with Male President }\end{array}$ & 4.48 & $\begin{array}{c}\text { Mixed Male Team } \\
\text { with Female President }\end{array}$ & 3.74 & $\begin{array}{l}0.742 * \\
(0.082)\end{array}$ \\
\hline & & $\begin{array}{l}\text { Male } \\
\text { Team }\end{array}$ & 4.54 & $\begin{array}{c}\text { Mixed Male Team } \\
\text { with Female President }\end{array}$ & 3.74 & $\begin{array}{l}0.800 * * \\
(0.047)\end{array}$ \\
\hline
\end{tabular}

Regarding the management by exception factor, results indicate that, in general, management teams extensively supervise the errors occurring in a company and try to correct them so they will not reoccur in the future. Such supervision controlling business standards is more intensive in female teams (4.61), male teams (4.54), and mixed female teams with a male president (4.48), with significant differences to mixed male teams directed by women (3.74). Again, hypothesis 3 is rejected, while hypothesis 4 is partially confirmed. 


\section{Discussion}

Leaders have the goal to promote, motivate, and cultivate a vision that favors the achievement of organizational objectives, particularly in cooperatives, due to the strong interrelationship between shareholders and the workforce. The progressive advancement of women to management positions is a necessity, justified by cooperative values (democratic, participative, and egalitarian management), their growing presence as female members in these organizations, and the positive effects that they provide through their leadership style, demonstrated by many studies.

This study reveals that both leadership styles (transformational and transactional) are widely implemented among cooperative managers (an average of 4.30 and 4.24 over 5, respectively), with no significant gender differences in the use of either leadership style in the cooperatives analyzed. Therefore, this research corroborates that both transformational and transactional leadership are similarly used, with the transformational style no more frequently implemented than the transactional one, not supporting H1 and empirically corroborating the ideas of Bass, and Avolio [44] or Eti-Tofinga et al. [34] in cooperatives. This may be a reflection that cooperative principles and values have greater weight in the implementation of leadership styles than the gender stereotypes indicated in other studies.

Regarding transformational leadership, the level of its use among male and female managers is identical (4.30 and 4.31, respectively). Specifically, these characteristics create a setting that favors equality among men and women in cooperatives and justifies the lack of gender differences in the transformational leadership style implemented. In terms of its components, idealized influence behavior, individualized consideration, and idealized influence attributed are the most developed among both men and women in cooperatives, in contrast with intellectual stimulation and inspirational motivation.

Regarding transactional leadership, female and male managers develop it at a similar level in cooperatives. Considering their components, management by exception and contingent reward have high levels of implementation among male and female managers, with no observable gender differences. Furthermore, both leadership styles analyzed are equally developed among male and female managers in the cooperatives of associated work and no gender differences in the leadership styles employed by male and female managers have been found; supporting H2. This result is compatible with Komives [50], Van Engen et al.'s [64], Vecchio's [52], and Stewart and McDermott's [53] contributions. This finding is important, especially in cooperatives, where the values of equality, democracy, and equity are fundamental; confirming the adequate use of these cooperative values in cooperative managerial positions. Particularly, this result may be a result of the great importance of member economic participation as a cooperative principle [45], where the clarification of expectations and recognition of performance are key, mainly among working partners.

To delve more deeply into possible effects on leadership styles, the composition of management teams of cooperatives on the implementation of transformational and transactional leadership styles has been analyzed. Regarding transformational leadership, it is more often implemented by male management teams and female management teams than by mixed male management teams with a female president. In addition, mixed management teams whose leader is a man exercise greater levels of transformational leadership than those led by a woman. Transactional leadership is more often implemented by the female team than by the mixed male team with a female president. Consequently, there are differences in leadership styles developed by management teams led by men and women in cooperatives; not giving support to H3. These results are in line with Eagly et al. [79], Heilman and Okimoto [80], and Brescoll [81].

Likewise, management teams made up only of men or women are those that implement the different components of transformational leadership to a greater extent. However, in regard to transactional leadership, female teams employ contingent reward to a greater extent, while male teams implement management by exception to a greater degree. Consequently, for homogenous teams (female teams and male teams), there are significant gender differences in the transactional leadership style employed, not totally giving support to $\mathrm{H} 4$. 
Surprisingly, reduced evaluations by mixed female teams with a male president have not been observed, which indicates that women are used to having male leaders, and they are less critical than their male counterparts of female leaders. The reasons for this situation are: (a) Women accept male managers being dominant, and (b) gender restrictions about women not being dominant [99].

Female presidents of mixed male teams seem to develop a lower level of transformational and transactional leadership in EESs because employees probably prefer male over female supervision [84]. Male authority is better accepted than female authority, reducing the consideration toward female managers by their male colleagues [80]. Followers have different stereotypes toward female managers than male managers because they expect inferior performance from women [44]. In fact, female managers face social and economic reserve from males when they develop managerial positions $[81,83]$. Additionally, female leaders seem to develop less effective values and behavior associated with successful leadership, such as warmth, politeness, and flexibility; whereas men may use assertiveness, decisiveness, and confidence [89,90], values more often associated with successful and achievement-oriented executives [91,92]. Furthermore, female managers are threatening [99] and less trustworthy [101] than males, as well as being less often linked to power [91,92]. Finally, women leaders seem to be punished for not achieving prescribed, communal beliefs [80], using different stereotypes, and gender rules [82,97,98]. Consequently, all the previous reasons justify their underrepresentation in decision-making processes and powerful positions [102].

\section{Conclusions}

In a social and cultural context characterized by gender inequality and the growing interest in the promotion and expansion of sustainable development in our society, gender equality plays a key role in the achievement of sustainability principles and values. Cooperatives, as SEEs, are a way to solve this situation because their characteristics and leadership styles determine their commitment to SDGs. There is no research that empirically examines the transformational and transactional leadership styles of male and female managers in the context of cooperatives. Therefore, the main goal of this study is to analyze transformational and transactional leadership from a gender perspective in the context of Spanish cooperatives, considering their contribution to SDGs. Therefore, which leadership style is more often used by cooperatives, whether there are gender differences in the development of these styles and the effect of management team composition in these gender differences is empirically analyzed with a sample made up of 114 cooperatives of associated work. From these results, other conclusions about how female managers may obtain better success and assessment in their roles of leading management teams in cooperatives, or which cooperative management teams are more effectively managed by female directors, are explored.

Cooperatives, with their principles and values, contribute to SDGs, specifically SDG 1, SDG 5 , SDG 8, and SDG 10. The ways in which leadership style help to achieve these objectives have been theoretically demonstrated with the review of the literature. The findings show that transformational and transactional leadership are similarly used. It has also been proven that there are no significant gender differences in their use. Both results reflect that the nature and values of cooperatives have more importance in the development of leadership styles than gender stereotypes. Furthermore, these findings support an assumption that the cultural context of the organization should be considered as a key element in understanding leadership styles [34].

The empirical study also analyzes whether there are gender differences in the use of leadership styles considering the composition of management teams, which reveals some significant differences in the implementation of transformational and transactional leadership styles. Both styles are significantly less often used by mixed male management teams with a female president than in homogeneous teams. Consequently, we can deduce that it is not advisable to have a management team made up of men and led by a woman since men do not positively value the leadership style that the female president implements. Therefore, it is recommended that cooperatives that have this type of management team should incorporate more women in management teams in order to improve their view of the leader and 
avoid the penalization experienced by female presidents. Consequently, it is recommendable to create mixed management teams that develop leadership styles, which satisfy both male and female followers as well as male and female members. This proposal can help to make management easier for female directors of management teams, preventing and eliminating the principle barriers male members have. Acceptance of plurality in mixed management teams may improve female managers' performance and success in their roles of leading management teams as well as enhancing their followers' perceptions of their work and results. Therefore, female managers could obtain better success in cooperatives looking for a balance between the presence of men and woman (answering research questions (a) and (b)).

The role of leader, even in cooperatives, is more often linked to males than females, with females being less visible and less well considered than their male colleagues. Moreover, women need to work harder and demonstrate better results than their masculine peers to be viewed as equally competent. To avoid this situation, it is necessary to develop some guidelines in cooperative companies to eliminate this gap. First, top managers need to set objectives for promoting more females into first-level management positions, providing trust and empowerment to female employees so they can perform their jobs well and become managers. When there are significantly more women managers, more females will rise to management positions and, progressively, more females in management will arrive to senior leadership positions. It is vital to build a collective awareness of the importance of the promotion gap on the lowest level because women are willing to do what it takes to aspire to managerial positions. Second, senior-level women should be promoted to higher levels in the hierarchy, increasing their representation in senior positions in their cooperatives. Therefore, female senior managers must foment the progressive presence of women in senior management teams. Third, the view of employees about the presence of female senior leaders in their company should be less optimistic and more oriented toward an objective and equity view, favoring the progressive entrance of women into senior management positions.

Fourth, HR leaders should focus on empowering some organizational and cultural changes to extend women's opportunities, such as: (a) Supporting the figure of female authority and power as equal to male authority, (b) promoting similar professional career among males and females, and (c) increasing woman's visibility by showing similar probabilities of their obtaining good business performance in cooperatives as men.

Fifth, HR managers should provide adequate work-life balance programs to resolve employees' work-family conflicts since their availability and use positively contributes to profitability $[113,114]$. Sixth, managers should organize training courses and networking activities in a way that promotes the social values and principles of cooperatives (equality, solidarity, democracy). Seventh, managers should establish the relevant leadership characteristics sought by the organization in the selection process, such as strong leadership skills, being good at managing people, and having good analytical skills. These organizational policies and recommendations should be implemented to improve the presence and assessment/consideration of female managers (research question (c)).

The previous recommendations will increase female directors' satisfaction in their role (research question (e)) because they will be better assessed by their counterparts (peers and followers); facilitating the retention of talented female managers. To obtain better results, some barriers (stereotypes, strict and low female evaluation, low female authority and power, and different values of successful leadership, among others) should be eliminated, transforming organizational culture to cooperative values (equality, equity, solidarity, responsibility, and democracy) so that female directors can receive better and fairer assessment. Therefore, the main barriers that prevent female managers from implementing their leadership styles effectively in cooperatives have been identified (research question (d)).

As different leadership styles can coexist in cooperatives in general, and in management teams in particular, it is necessary to make different leadership styles compatible (research question (f)). Cooperative values play a key role in their successful integration and joint operation, improving managerial performance. 
The study highlights the main barriers that prevent the implementation of appropriate levels of female leadership and provides a useful guide to managing these barriers and empowering female managers. These proposals will help to retain the most talented managers (research question (g)) and favor the improvement of gender equality in cooperatives (research question (h)).

For all these reasons, this study has practical and social implications that facilitate sustainable development, as well as achieving some of the established SDGs (research question i), such as gender equality (SDG 5), decent work and economic growth (SDG 8), and the reduction of inequalities (SDG 10). The greater presence of women in cooperatives than in other organizations improves their socio-professional position and economic income, consequently, reducing poverty (SDG 1). Findings indicate that the special characteristics of cooperatives contribute to a more egalitarian development of leadership styles where female managers need to improve the perception of their role among male management teams. Therefore, understanding how leadership styles function in relation to their manager's gender is an essential step toward achieving a more sustainable entity. Cooperatives contribute by creating a solid economic foundation that preserves employment and improves employees' labor conditions. Value-based organizations need leaders to respect and respond to the necessity of the community.

Although this study provides results that contribute to the understanding of the principal factors that define leadership styles, it also has certain limitations. Future studies should introduce variables of age and size, to see whether it is more probable to find female managers in younger and smaller companies. Another line of research could be to broaden the sample to include different economic sectors in order to analyze the possible differences among them. It would also be a good idea to analyze whether there is a significant relationship between the leadership style implemented by a management team and the performance of the organization. Furthermore, the fact that the majority of the cooperatives analyzed belong to the area of education has an impact on the results obtained, as in this type of institution, women experience less vertical segregation. However, given the scarcity of empirical studies that analyze gender equality and leadership in the SE, the relevance of the results of this study lie in its practical implications.

Author Contributions: Conceptualization, I.M.M.-L., M.M.-V., I.O.-C., and N.A.-L.; data curation, N.A.-L.; methodology, I.M.M.-L., M.M.-V., and I.O.-C.; formal analysis: I.M.M.-L., M.M.-V., and I.O.-C.; validation: I.M.M.-L., M.M.-V., and I.O.-C.; writing-original draft preparation, I.M.M.-L., M.M.-V., I.O.-C., and N.A.-L. All authors have read and agreed to the published version of the manuscript.

Funding: This research was funded by Dirección General de Relaciones Laborales y Economía Social. Consejería de Desarrollo Económico, Turismo y Empleo. Comunidad Autónoma de la Región de Murcia. Grant number 2016-99-13-0002.

Conflicts of Interest: The authors declare no conflict of interest.

\section{References}

1. World Commission on Environment and Development (WCED). Our Common Future; Oxford University Press: Oxford, UK, 1987.

2. Mindt, L.; Rieckmann, M. Desarrollo de las competencias para el emprendimiento orientado a la sostenibilidad en la educación superior: Una revisión bibliográfica de los métodos de enseñanza y aprendizaje. Teor. Educ. Rev. Interuniv. 2017, 29, 129-159. [CrossRef]

3. Chaves, R.; Monzón Campos, J.L. The Social Economy in the European Union; CESE/COMM/05/2005; CIRIEC International and The European Economic and Social Committee (EESC): Brussels, Belgium, 2007.

4. Defourny, J.; Laville, J.-L. Pour une économie sociale revisitée. Rev. Nouv. 2007, 122, 78-83.

5. Chaves-Ávila, R.; Monzón-Campos, J.L.; Pérez-Uralde, J.M.; Adrigán, M. La economía social en clave internacional. Cuantificación, reconocimiento institucional y visibilidad social en Europa, Iberoamérica y Norte de África. REVESCO Rev. Estudios Coop. 2013, 112, 122-150. [CrossRef]

6. Borzaga, C.; Salvatori, G.; Bodini, R. Social and Solidarity Economy and the Future of Work; Euricse Working Paper for the ILO; ITC/ILO: Turin, Italy, 2017. 
7. Utting, P. Achieving the Sustainable Development Goals through Social and Solidarity Economy: Incremental versus transformative change; Working Paper No.1 of the Knowledge Hub Working Paper Series; UN Inter-Agency Task Force on Social and Solidarity Economy; United Nations Research Institute for Social Development: Geneva, Switzerland, 2018. Available online: http://www.unrisd.org/80256B3C005BCCF9/ search/DCE7DAC6D248B0C1C1258279004DE587?OpenDocument (accessed on 7 February 2019).

8. CEPES. La Contribución de la Economía Social a los Objetivos de Desarrollo Sostenible. $4^{\circ}$ Informe Sobre la Experiencia de las Empresas Españolas de Economía Social en la Cooperación Al desarrollo 2017-19. 2020. Available online: https://www.cepes.es/files/publicaciones/117.pdf (accessed on 11 February 2020).

9. CEPES. Análisis del Impacto Socioeconómico de los Valores y Principios de la Economía Social en España. 2020. Available online: https://www.cepes.es/files/publicaciones/118.pdf (accessed on 21 April 2020).

10. Mozas, A. Contribución de las Cooperativas Agrarias al Cumplimiento de los Objetivos de Desarrollo Sostenible. Especial Referencia al Sector Oleícola; Ciriec-España: Valencia, Spain, 2019.

11. Huybrechts, B. Social Enterprise, Social Innovation and Alternative Economies: Insights from Fair Trade and Renewable Energy. In Alternative Economies and Spaces. New Perspectives for a Sustainable Economy; Zademach, H.-M., Hillebrand, S., Eds.; Transcript Global Studies: Bielefeld, Germany, 2013; pp. 113-130.

12. Hudon, M.; Huybrechts, B. From distant neighbours to bedmates: Exploring the synergies between the social economy and sustainable development. Ann. Public Coop. Econ. 2017, 88, 141-154. [CrossRef]

13. Bastida, M.; Vaquero García, A.; Cancelo Márquez, M.; Olveira Blanco, A. Fostering the Sustainable Development Goals from an Ecosystem Conducive to the SE: The Galician's Case. Sustainability 2020, 12, 500. [CrossRef]

14. Wanyama, F.O. Cooperatives and the Sustainable Development Goals: A Contribution to the Post-2015 Development Debate. A Policy Brief; International Labour Organisation: Geneva, Switzerland, 2014.

15. Quiroz-Niño, C.; Murga-Menoyo, M.Á. Social and Solidarity Economy, Sustainable Development Goals, and Community Development: The Mission of Adult Education \& Training. Sustainability 2017, 9, 2164.

16. Tremblay, C.; Gutberlet, J. Empowerment through participation: Assessing the voices of leaders from recycling cooperatives in Sao Paulo, Brazil. Community Dev. J. 2012, 47, 282-302. [CrossRef]

17. Battilana, J.; Sengul, M.; Pache, A.C.; Model, J. Harnessing productive tensions in hybrid organizations: The case of work integration social enterprises. Acad. Manag. J. 2015, 58, 1658-1685. [CrossRef]

18. Monzón, J.L.; Chaves, R. The European social economy: Concept and dimensions of the third sector. Ann. Public Coop. Econ. 2008, 79, 549-577. [CrossRef]

19. Sáez-Fernández, F.J.; Picazo-Tadeo, A.J.; Llorca-rodríguez, C.M. Do labour societies perform differently to cooperatives? Evidence from the Spanish building industry. Ann. Public Coop. Econ. 2012, 83, 61-81. [CrossRef]

20. Mozas, A.; Puentes, R. La responsabilidad social corporativa y su paralelismo con las sociedades cooperativas. REVESCO. Rev. Estudios Coop. 2010, 103, 75-100.

21. International Co-Operative Alliance (2017): Co-Ops for 2030: A Movement Achieving Sustainable Development for All. Available online: https://www.ica.coop/sites/default/files/publication-files/co-ops-for2030-final-report-vol-1-2017-1105233539.pdf (accessed on 12 February 2020).

22. Carrasco, I. Corporate social responsibility, values and cooperation. Int. Adv. Econ. Res. 2007, 13, 454-460. [CrossRef]

23. Baamonde, E. El cooperativismo agroalimentario. In El Nuevo Sistema Agroalimentario en Una Crisis Global; Lamo, J., Coord, Eds.; Colección Mediterráneo Económico: Almería, Spain, 2009; Volume 15, pp. $229-246$.

24. Garrido-Chamorro, C. Estructura del cooperativismo agroalimentario en España. In El Papel del Cooperativismo Agroalimentario en la Economía mundial, Colección Mediterráneo Económico 24; Cajamar Caja Rural: Almería, Spain, 2013; pp. 173-190.

25. Valiente Palma, L. ¿Podría estar contribuyendo el cooperativismo a fijar la población en el territorio de Andalucía? CIRIEC-España Rev. Econ. Publica Soc. Coop. 2019, 97, 49-74. [CrossRef]

26. European Commission. Social Economy in the EU. 2018. Cooperatives. Available online: https://ec.europa. eu/growth/sectors/social-economy/cooperatives (accessed on 14 April 2020).

27. McKinsey and the Lean In Foundation (2019). Women in the Workplace Report. Available online: https://wiw-report.s3.amazonaws.com/Women_in_the_Workplace_2019.pdf (accessed on 27 April 2020).

28. Dezsö, C.L.; Ross, D.G. Does female representation in top management improve firm performance? A panel data investigation. Strateg. Manag. J. 2012, 33, 1072-1089. [CrossRef] 
29. Hambrick, D.; Mason, P. Upper echelons theory: The organizations as a reflection of its top managers. Acad. Manag. Rev. 1984, 9, 193-206. [CrossRef]

30. Haleblian, J.; Finkelstein, S. Top management team size, CEO dominance and firm performance. Acad. Manag. J. 1993, 36, 844-863.

31. Zaccaro, S. Leader resources and the nature of organizational problems: Commentary on Cognitive resources and leadership. Appl. Psychol. 1995, 44, 32-36. [CrossRef]

32. Shamir, B.; House, R.; Arthur, M. The motivational effects of charismatic leadership: A self-concept based theory. Organ. Sci. 1993, 4, 577-594. [CrossRef]

33. Vigoda-Gadot, E. Leadership style, organizational politics, and employees' performance. Pers. Rev. 2007, 36, 661-683. [CrossRef]

34. Eti-Tofinga, B.; Douglas, H.; Singh, G. Influence of evolving culture on leadership: A study of Fijian cooperatives. Eur. Bus. Rev. 2017, 29, 534-550. [CrossRef]

35. Pierce, J.L.; Newstrom, J.W. Leaders \& the Leadership Process; McGraw-Hill Irwin: New York, NY, USA, 2006.

36. Bass, B.M. Bass E Stogdill's Handbook of Leadership: Theory, Research, and Managerial Applications, 3rd ed.; Free Press: Nueva York, NY, USA, 1990.

37. Eagly, A.H.; Johannesen-Schmidt, M.C. The leadership styles of women and men. J. Soc. Issues 2001, 57, 781-797. [CrossRef]

38. Evkall, G.; Ryhammar, L. Leadership style, social climate and organizational outcomes: A study of a Swedish University College. Creat. Innov. Manag. 1997, 7, 126-130.

39. Bass, B.M. Leadership and Performance Beyond Expectation; Free Press: Nueva York, NY, USA, 1985.

40. Bass, B.M.; Avolio, B.J. Full Range Leadership Development, Manual for the Multifactor Leadership Questionnaire; Mind Garden: Redwood City, CA, USA, 1997.

41. Bass, B.M.; Riggio, R.E. Transformational Leadership; Lawrence Erlbaum Associates: Mahwah, NJ, USA, 2006.

42. Bass, B.M. Two decades of research and development in transformational leadership. Eur. J. Work Organ. Psychol. 1999, 8, 9-32. [CrossRef]

43. Cardona, P. El liderazgo relacional. In Raíces Éticas del Liderazgo; Melé, D., Ed.; Ediciones Universidad de Navarra: Pamplona, Spain, 2000.

44. Bass, B.M.; Avolio, B.J. Shatter the Glass Ceiling: Woman May Make Better Managers. Hum. Resour. Manag. 1994, 33, 549-560. [CrossRef]

45. Arcas Lario, N.; Martínez León, I.M.; De Miguel Gómez, M.D.; Martínez-Victoria, M.C.; Olmedo Cifuentes, I.; López Becerra, E.I. Participación de la mujer en la Economía Social. Aplicación a la Región de Murcia; Consejería de Desarrollo Económico, Turismo y Empleo: Comunidad Autónoma de Murcia, Spain, 2016.

46. Hanssmann, H. The Ownership of Enterprise; The Belknap of Harvard University Press: Cambridge, UK, 1996.

47. Nilsson, J. The nature of cooperative values and principles. Transaction cost theoretical explanations. Ann. Public Coop. Econ. 1996, 67, 633-653. [CrossRef]

48. Soboh, R.; Oude-Lansink, A.; Giensen, G.; Van Djik, G. Performance measurement of the agricultural marketing cooperatives: The gap between theory and practice. Rev. Agric. Econ. 2009, 31, 446-469. [CrossRef]

49. Mendoza, I.A.; Escobar, G.R.; García, B.R. Influencia del liderazgo transformacional en algunas variables de satisfacción organizacional en personal docente y administrativo de una institución pública de educación media superior. Nueva Época 2012, 10, 189-206.

50. Komives, S. The relationship of same- and cross-gender work pairs to staff performance and supervisor leadership in residence hall units. Sex Roles 1991, 24, 355-363. [CrossRef]

51. Van Engen, M.; Van Der Leeden, R.; Willemsen, T.M. Gender, context and leadership styles: A field study. J. Occup. Organ. Psychol. 2001, 74, 581-598. [CrossRef]

52. Vecchio, R.P. In search of gender advantage. Leadersh. Q. 2003, 14, 835-850. [CrossRef]

53. Stewart, J.; Mcdermott, C. Gender in psychology. Ann. Rev. Psychol. 2004, 55, 519-544. [CrossRef] [PubMed]

54. Rosener, J.B. Ways women lead. Harv. Bus. Rev. 1990, 68, 119-120. [PubMed]

55. Eagly, A.H.; Johnson, B.T. Gender and leadership style: A meta-analysis. Psychol. Bull. 1990, 108, $233-256$. [CrossRef]

56. Druskat, V. Gender and leadership style: Transformational and transactional leadership in the roman catholic church. Leadersh. Q. 1994, 5, 99-119. [CrossRef] 
57. Bass, B.M.; Avolio, B.J.; Atwater, L. The Transformational and Transactional Leadership of Men and Women. Appl. Psychol. Int. Rev. 1996, 45, 5-34. [CrossRef]

58. Eagly, A.H.; Carli, L.L. The female leadership advantage: An evaluation of the evidence. Leadersh. Q. 2003, 14, 807-834. [CrossRef]

59. Rosen, B.; Jerdee, T.H. Influence of sex role stereotypes on personnel decisions. J. Appl. Psychol. 1974, 59, 9-14. [CrossRef]

60. Van Engen, M.L.; Willemsen, T.K. Sex and leadership styles: A meta-analysis of research published in the 1990s. Psychol. Rep. 2004, 94, 3-18. [CrossRef]

61. Cuadrado, I.; Navas, M.; Molero, F.; Ferrer, E.; Morales, J.F. Gender differences in leadership styles as a function of leader and subordinates' sex and type of organization. J. Appl. Soc. Psychol. 2012, 42, 3083-3113. [CrossRef]

62. Doherty, A. The effect of leaders characteristics on the perceived transformational/transactional leadership and impact of interuniversity athletic administrators. J. Sports Med. 1997, 11, 275-285. [CrossRef]

63. Carless, S.A. Gender differences in transformational leadership: An examination of superior, leader, and subordinate perspectives. Sex Roles 1998, 39, 887-902. [CrossRef]

64. Eagly, A.H.; Johannensen-Schmidt, M.C.; Van Engen, M.L. Transformational, transactional, and laissez-faire leadership styles: A meta-analysis comparing women and men. Psychol. Bull. 2003, 117, 125-145. [CrossRef] [PubMed]

65. Sahin, F.; Gürbüz, S.; șeșen, H. Leaders' managerial assumptions and transformational leadership: The moderating role of gender. Leadersh. Organ. Dev. J. 2017, 38, 105-125. [CrossRef]

66. Maher, K.J. Gender-related stereotypes of transformational and transactional leadership. Sex Roles 1997, 37, 209-225. [CrossRef]

67. Manning, T.T. Gender, managerial level, transformational leadership and work satisfaction. Women Manag. Rev. 2002, 17, 207-216. [CrossRef]

68. Mandell, B.; Pherwani, S. Relationship between emotional intelligence and transformational leadership style: A gender comparison. J. Bus. Psychol. 2003, 17, 387-404. [CrossRef]

69. Brown, F.W.; Reilly, M.D. Emotional intelligence, transformational leadership and gender: Correlation and interaction possibilities. J. Int. Manag. Stud. 2008, 3, 1-9.

70. Fregidou, M. ¿Es necesario equilibrar el poder en las cooperativas entre mujeres y hombres? CIRIEC-España Rev. Econ. Publica Soc. Coop. 2004, 50, 151-163.

71. Berenguer, G.; Cerver, E.; De La Torre, A.; Torcal, V.R. El estilo directivo de las mujeres y su influencia sobre la gestión del equipo de trabajo en las cooperativas valencianas. CIRIEC-España, Rev. Econ. Publica Soc. Coop. 2004, 50, 123-149.

72. Sanchez-Marin, G.; Baixauli-Soler, J.S. CEO reputation and top management team compensation. Manag. Decis. 2014, 52, 540-558. [CrossRef]

73. Baixauli-Soler, J.S.; Belda-Ruiz, M.; Sanchez-Marin, G. Executive stock options, gender diversity in the top management team, and firm risk taking. J. Bus. Res. 2015, 68, 451-463. [CrossRef]

74. Loden, M. Feminine Leadership, or how to Succeed in Business without Being One of the Boys; Times Books: New York, NY, USA, 1985.

75. Nielsen, S.; Huse, M. Women directors' contribution to board decision-making and strategic involvement: The role of equality perception. Eur. Manag. Rev. 2010, 7, 16-29. [CrossRef]

76. Faccio, M.; Marchica, M.T.; Mura, R. CEO gender, corporate risk-taking, and the efficiency of capital allocation. J. Corp. Financ. 2016, 39, 193-209. [CrossRef]

77. Harel, G.H.; Tzafrir, S.S.; Baruch, Y. Achieving organizational effectiveness through promotion of women into managerial positions: HRM practice focus. Int. J. Hum. Resour. Manag. 2003, 14, 247-263. [CrossRef]

78. Carter, D.A.; Simkins, B.J.; Simpson, W.G. Corporate governance, board diversity, and firm value. Financ. Rev. 2003, 38, 33-53. [CrossRef]

79. Eagly, A.H.; Makhijani, M.G.; Klonsky, B.G. Gender and the evaluation of leaders: A meta-analysis. Psychol. Bull. 1992, 111, 3-22. [CrossRef]

80. Heilman, M.E.; Okimoto, T.G. Why are women penalized for success at male tasks? The implied communality deficit. J. Appl. Psychol. 2007, 92, 81-92. [CrossRef]

81. Brescoll, V.L. Who takes the floor and why: Gender, power, and volubility in organizations. Adm. Sci. Q. 2011, 56, 622-641. [CrossRef] 
82. Rudman, L.A. Self-promotion as a risk factor for women: The costs and benefits of counterstereotypical impression management. J. Personal. Soc. Psychol. 1998, 74, 629-645. [CrossRef]

83. Sinclair, L.; Kunda, Z. Motivated stereotyping of women: She's fine if she praised me but incompetent if she criticized me. Personal. Soc. Psychol. Bull. 2000, 26, 1329-1342. [CrossRef]

84. Rifkin, R. Americans still Prefer a Male Boss to a Female Boss. Gallup Economy, 2001. 2014. Available online: http://www.gallup.com/poll/178484/americans-prefer-male-boss-female-boss.aspx (accessed on 11 February 2020).

85. Elsesser, K.M.; Lever, J. Does gender bias against female leaders persist? Quantitative and qualitative data from a large-scale survey. Hum. Relat. 2011, 64, 1555-1578. [CrossRef]

86. Heilman, M.E. Description and prescription: How gender stereotypes prevent women's ascent up the organizational ladder. J. Soc. Issues 2001, 57, 657-674. [CrossRef]

87. Ridgeway, C.L. Gender, status, and leadership. J. Soc. Issues 2001, 57, 637-655. [CrossRef]

88. Eagly, A.H.; Karau, S.J. Role congruity theory of prejudice toward female leaders. Psychol. Rev. 2002, 109, 573-598. [CrossRef] [PubMed]

89. Burgess, D.; Borgida, E. Who women are, who women should be: Descriptive and prescriptive gender stereotyping in sex discrimination. Psychol. Public Policy Law 1999, 5, 665-692. [CrossRef]

90. Prentice, D.; Carranza, E. What women and men should be, shouldn't be, are allowed to be, and don't have to be: The contents of prescriptive gender stereotypes. Psychol. Women Q. 2002, 26, 269-281. [CrossRef]

91. Schein, V.E.; Davidson, M.J. Think manager, think male. Manag. Dev. Rev. 1993, 6, 33-41. [CrossRef]

92. Koenig, A.M.; Eagly, A.H.; Mitchell, A.A.; Ristikari, T. Are leader stereotypes masculine? A meta-analysis of three research paradigms. Psychol. Bull. 2011, 137, 616-642. [CrossRef]

93. Vial, A.C.; Napier, J.L. Powerful differences: Gender and the psychology of power. In Proceedings of the 10th Biennial Conference of the Society for the Psychological Study of Social Issues, Portland, OR, USA, 27-29 June 2014.

94. Eagly, A.H. Achieving relational authenticity in leadership: Does gender matter? Leadersh. Q. 2005, 16, 459-474. [CrossRef]

95. Lyness, K.S.; Heilman, M.E. When fit is fundamental: Performance evaluations and promotions of upper-level female and male managers. J. Appl. Psychol. 2006, 91, 777-785. [CrossRef]

96. Ayman, R.; Korabik, K.; Morris, S. Is transformational leadership always perceived as effective? Male subordinates' devaluation of female transformational leaders. J. Appl. Soc. Psychol. 2009, 39, 852-879.

97. Rudman, L.A.; Fairchild, K. Reactions to counterstereotypic behavior: The role of backlash in cultural stereotype maintenance. J. Personal. Soc. Psychol. 2004, 87, 157-176. [CrossRef] [PubMed]

98. Moss-Racusin, C.A.; Rudman, L.A. Disruptions in women's self-promotion: The backlash avoidance model. Psychol. Women Q. 2010, 34, 186-202. [CrossRef]

99. Rudman, L.A.; Moss-Racusin, C.A.; Phelan, J.E.; Nauts, S. Status incongruity and backlash effects: Defending the gender hierarchy motivates prejudice against female leaders. J. Exp. Soc. Psychol. 2012, 48, 165-179. [CrossRef]

100. Williams, M.J.; Tiedens, L.Z. The subtle suspension of backlash: A meta-analysis of penalties for women's implicit and explicit dominance behavior. Psychol. Bull. 2016, 142, 165-197. [CrossRef]

101. Heilman, M.E.; Wallen, A.S.; Fuchs, D.; Tamkins, M.M. Penalties for success: Reactions to women who succeed at male gender-typed tasks. J. Appl. Psychol. 2004, 89, 416-423. [CrossRef]

102. CATALYST. Women in the Workforce-United States: Quick Take. 2014. Available online: https://www. catalyst.org/research/women-in-the-workforce-united-states/ (accessed on 7 February 2020).

103. Morrison, A.M.; Von Glinow, M.A. Women and minorities in management. Am. Psychol. 1990, 45, $200-208$. [CrossRef]

104. Heilman, M.E.; Haynes, M.C. No credit where credit is due: Attributional rationalization of women's success in male-female teams. J. Appl. Psychol. 2005, 90, 905-916. [CrossRef]

105. Bass, B.M.; Avolio, B.J. Transformational Leadership Development: Manual for de Multifactor Leadership Questionnaire; Consulting Psychologists Press: Palo Alto, CA, USA, 1990.

106. Barberá, E.; Sarrió, M.; Ramos, A. Mujeres Directivas: Promoción Profesional en España y Reino Unido; Collecció Quaderns Feministes (2); Institut Universitari d 'Estudis de la Dona: Valencia, Spain, 2000. 
107. Molero, F.; Recio, P.; Cuadrado, I. Liderazgo transformacional y liderazgo transaccional: Un análisis de la estructura factorial del Multifactor Leadership Questionnaire (MLQ) en una muestra española. Psicothema 2010, 22, 495-501.

108. Antonakis, J.; Avolio, B.J.; Sivasubramaniam, N. Context and leadership: An examination of the nine-factor full-range leadership theory using the Multifactor Leadership Questionnaire. Leadersh. Q. 2003, 14, 261-295. [CrossRef]

109. Muenjohn, N.; Armstrong, A. Evaluating the structural validity of the multifactor leadership questionnaire (MLQ), capturing the leadership factors of transformational-transactional leadership. Contemp. Manag. Res. 2008, 4, 3-14. [CrossRef]

110. Hemsworth, D.; Muterera, J.; Baregheh, A. Examining Bass's transformational leadership in public sector executives: A psychometric properties review. J. Appl. Bus. Res. 2013, 29, 853-862. [CrossRef]

111. Avolio, B.J.; Bass, B.M. Multifactor Leadership Questionnaire, 3rd ed.; Mind Garden: Palo Alto, CA, USA, 2004.

112. Cronbach, L.J. Coefficient alpha and the internal structure of tests. Psychometrika 1951, 16, 297-334. [CrossRef]

113. Martínez-León, I.M.; Olmedo-Cifuentes, I.; Sánchez-Vidal, M.E. Relationship between availability of WLB practices and financial results. Pers. Rev. 2019, 48, 935-956. [CrossRef]

114. Shin, D.; Enoh, J. Availability and Use of Work-Life Balance Programs: Relationship with Organizational Profitability. Sustainability 2020, 12, 2965. [CrossRef]

(C) 2020 by the authors. Licensee MDPI, Basel, Switzerland. This article is an open access article distributed under the terms and conditions of the Creative Commons Attribution (CC BY) license (http://creativecommons.org/licenses/by/4.0/). 